\title{
Laboratory Scale Modelling and the Treatment of Biomedical Wastes Through Herbaceuticals for Manure Production
}

\author{
E.D. Viswanath ${ }^{1}$, N. Balasundaram ${ }^{* 2}$, T. Senthil Vadivel ${ }^{3}$ \\ ${ }^{1} P G$ Student, Department of Civil Engineering, Karpagam Academy of Higher Education, Coimbatore - 641021. Tamilnadu. \\ ${ }^{2}$ Professor \& Head, Department of Civil Engineering, Karpagam Academy of Higher Education, Coimbatore - 641021. Tamilnadu. \\ ${ }^{3}$ Professor \& Head, Department of Civil Engineering, School of Engineering \& Technology, Adamas University, Kolkata - 700126. West \\ Bengal \\ *Email: balasudaram49@gmail.com
}

\begin{abstract}
Biomedical waste disposal practices are becoming important in both the developing and developed countries and need to be properly followed by the human being. An effective utilization of waste helps to have potent products like biofertilizer, bio-manure and also mineral resources like $\mathrm{Ca}, \mathrm{Mg}, \mathrm{Fe}$, Co etc. The present study involves the treatment of biomedical waste by applying primary treatment using seaweeds (Padina tetrastromatica and Amphiroa fragilissima) and herboceuticals (turmeric \& neem extracts). The experiments were designed to find out the optimum concentration of the substrate, incubation period and time in the treatment process. The secondary treatment process consisted of alkaline hydrolysis process with various concentrations to treat biomedical wastes. The bacterial load and count were analysed in all the treatment processes. The final characterization of the treated waste was analysed for the potential of biomanure production. The result revealed that the bacterial reduction efficacy and residual mass was found to be $15000 \mathrm{CFU} / \mathrm{mL}$ and 0.94 $\mathrm{g}$ at the end of the $4^{\text {th }}$ day, whereas the efficiencies optimized by RSM for bacterial count and residual mass were $16481.6 \mathrm{CFU} / \mathrm{mL}$ and $0.5426 \mathrm{~g}$ respectively. It was observed that bacterial count steadily decreased from 20000 to $5 \mathrm{CFU} / \mathrm{mL}$ of sample, when the temperature range varied from 30 to $75^{\circ} \mathrm{C}$. The results of bio-manure production showed that nitrogen and phosphorous contents were enriched after the treatment procedures and the moisture content was reduced to $<2 \%$.
\end{abstract}

Key words: Biomedical wastes, Herbaceuticals, seaweeds, bio-manure

\section{Introduction}

The management of the biomedical waste is an integral part of traditional and contemporary system of health care (Rajan et al., 2018). Proper biomedical waste management is an important factor in hospital cleanliness, hygiene, operational practices and maintenance activities. Effective BMW management (BMWM) is mandatory for maintaining a clean environment. (Datta et al., 2018). According to Cointreau-Levine (1997), the decomposition of waste into constituent chemicals is a common source of local environmental pollution. Waste management is the actions required to manage waste from its inception to its final disposal (UNSD, 2017). It includes the collection, segregation, transport, treatment and disposal with proper monitoring under government regulation. Medical care system is essential for our life and health, but the wastes generated from the hospitals like tissues, fluids, organs etc., creates more problems to the environment. There is a huge amount of potentially infectious and hazardous wastes generated by the hospitals. The aim of the $3 \mathrm{R}$ waste hierarchy is to utilize the maximum practical benefits in terms of biodegradable products to release the minimum amount of waste to the world (Albert and Raleigh, 2011). There should be an alternative method for the disposal of animal carcasses and slaughterhouse wastes, with the dual benefits of both eliminating waste material and producing energy (Insam et al., 2010). Most wastes are generated by the hospitals and medical clinics are nonhazardous general wastes from hospital organization activities such as human anatomical wastes, tissues, kitchen wastes, analytical laboratory wastes, office materials, workshop residuals, first aid packaging, used but emptied disposable bed liners, diapers and disposable masks. After the source segregation of recyclables, disposal is done typically by sanitary landfill. Biomedical general wastes of about 1.0 to $2.0 \mathrm{~kg} / \mathrm{bed} / \mathrm{day}$ and hazardous wastes of about 0.2 to $0.8 \mathrm{~kg} / \mathrm{bed} /$ day are generated. The treatment of biomedical waste with viable technology is an urgent need eliminate the risks to humans and to environment. Zokaei et al., 2013.

The current disposal techniques adopted for the biomedical waste management are incineration and land fill. It provides uncontrollable process factors which may release toxic substances into the air. And keeping biomedical wastes in storage container for long period leads to adverse side effects like high virulence among pathogens. The present study focuses on the development of a compact biomedical digester for hospitals and health care industries as an effective tool. It has the application of in-house disposal system of biological fluids and liquids for managing biomedical wastes. It focuses on the effective management of biomedical wastes incorporating waste reduction and neutralization. Alkaline hydrolysis and the tissue digesters were originally developed for the disposal of the radioactive animal carcasses generated from biomedical and pharmaceutical research. Plant species-mediated waste management will be the key idea of this current research work with cost effective strategy, when compared to conventional method. Seaweeds have good antimicrobial activity and bacteriostatic and bactericidal properties. Padina tetrastomatica and Amphipora fragilissia have good antibacterial activity (Sakthieswari and Srisudha, 2016). 
Curcuma longa are commonly used as flavouring agents, preservatives and colouring agents and also in biomedical applications. The rhizome isolates of turmeric possess a wide range of biological activities (Tilak et al., 2004; Kumar et al., 2006), and antibacterial activity (Gupta and Sadhana 2005; Naz et al., 2010). Effective waste management consists of five steps such as monitoring, co-operation, collection, transportation and disposal of wastes.

Aim: The present study focuses on biomedical waste converted into manure with the seaweed.

\section{Methodology}

\subsection{Material and Sampling Site}

The biomedical wastes (Category $3 \&$ 6) were collected from various hospitals in and around the Salem district of Tamil Nadu with prior permission. They were segregated based on different categories as per Biomedical Waste Management (BWM).

\subsection{Collection of Seaweeds and Turmeric}

Seaweeds such as Amphiroa fragilissima (KSR01) and Padina tetrastromatica (KSR02) were collected from Mandapam sea coast of Ramanathapuram, Tamil Nadu. It was authenticated by Rajendra Kumar, CSMCRI and voucher specimen was maintained at KSRCT culture collection centre, Namakkal, Tamil Nadu. Two varieties of turmeric samples (PTS10 and BSR) were collected from turmeric collection centre, Erode and were shade dried at $37^{\circ}$ $\mathrm{C}$ for about 3 days. The samples were powdered and transferred to a sterile air tight container and stored at room temperature.

\subsection{Optimization of Parameters to Reduce the Microbes}

Response surface methodology is an effective investigational tool used for developing and optimizing the process parameters with a combination of strong mathematical and statistical techniques (Zokaei et al., 2013). It can be used for evaluating the relative significance of different influencing factors, even in the presence of complex interactions.

\subsection{Primary treatment}

The primary treatment was designed with the aim of reducing bacterial population present in the biomedical wastes. Various substrates including seaweeds (Padina tetrastromatica and Amphiroa fragilissima) and turmeric were used to know their potential in waste management treatment process. All the experiments were conducted in $250 \mathrm{~mL}$ beaker having $100 \mathrm{~mL}$ of distilled water containing $50 \mathrm{gms}$ of tissue waste. In this present study, three effective parameters (Substrate concentration,

Agitation speed and Incubation time) were selected as variables to be applied for the design of the experiment (DOE) (Gerayeli et al., 2013).

\subsection{Secondary Treatment}

After completion of the Primary treatment, the samples with minimal bacterial load were taken to the secondary treatment procedure in which the sample underwent alkaline hydrolysis using $5 \% \mathrm{NaOH}$ for 2 hrs. After this, the experiment was conducted to analyze the bacterial load and percentage of waste digested. During the experiment, an effort was made to understand the influence of temperature on the treatment by conducting the experiments at different temperatures, and the period of experiment was also calculated in order to optimize the efficient protocol for effective treatment. Then the digested fraction was monitored and analysed for various chemical and biological parameters.

\subsection{The Influence of Temperature in the Treatment process}

To study the influence of temperature in the treatment procedure, the experiment was done at different temperatures $\left(30^{\circ} \mathrm{C}, 35^{\circ} \mathrm{C}\right.$, $40^{\circ} \mathrm{C}, 45^{\circ} \mathrm{C}, 50^{\circ} \mathrm{C}, 55^{\circ} \mathrm{C}, 60^{\circ} \mathrm{C}, 65^{\circ} \mathrm{C}, 70^{\circ} \mathrm{C}$ and $75^{\circ} \mathrm{C}$ ). To the $250 \mathrm{~mL}$ beaker, $100 \mathrm{~mL}$ of sterile distilled water and $50 \mathrm{~g}$ of collected waste was added. Thereafter the preliminary treatment was carried out with the selected substrate at optimized process parameters. After 3 days of primary treatment, the secondary treatment was carried out for $2 \mathrm{hrs}$. During the experiment, $\mathrm{pH}$ of the sample was measured using a calibrated $\mathrm{pH}$ meter at every $6 \mathrm{~h}$ interval. At the end of the treatment, the supernatants were filtered using a $0.45 \mu \mathrm{m}$ membrane and were analyzed looking for a reduction in the bacterial population using a culture sensitivity test.

\subsection{Bio-manure Preparation}

Neem leaf and turmeric were collected and kept shade dried for about two days. 10 gram of the sample were taken in $100 \mathrm{ml}$ of water and the aqueous extracts were separated. The aqueous extract of Neem leaf $(5 \% \mathrm{w} / \mathrm{v})$ was added to this sample to enhance the antibacterial activity of the final product. Finally, the sample was filtered and the residue air dried for 30 minutes and the powdered sample was analyzed for the presence of nutrients (NARES, 1999). Thereafter, pot analysis was done to check the efficiency of biomanure from treated tissue waste in the plant growth.

\section{Results and Discussion}

Table 1: Operational conditions for primary treatment procedure using different substrates

\begin{tabular}{|c|c|c|c|}
\hline Variable & Tested conditions & \multicolumn{2}{|c|}{ Fixed parameters } \\
\hline Substrate concentration & $\begin{array}{c}2.5,5.0,7.5,10.0,12.5, \\
\text { and } 15 \mathrm{~g} / 100 \mathrm{~mL} \\
\text { substrate }\end{array}$ & Agitation speed $100 \mathrm{rpm}$ & $\begin{array}{c}\text { Incubation time } \\
48 \mathrm{hrs}\end{array}$ \\
\hline Agitation speed & $\begin{array}{c}50,100,150,200 \mathrm{and} \\
250 \mathrm{rpm}\end{array}$ & $\begin{array}{c}\text { Substrate concentration } 10.0 \\
\mathrm{~g} / 100 \mathrm{~mL}\end{array}$ & $\begin{array}{c}\text { Incubation time } \\
48 \mathrm{hrs}\end{array}$ \\
\hline Incubation time & $\begin{array}{c}24,48,72,96, \text { and } 120 \\
\mathrm{hrs}\end{array}$ & $\begin{array}{c}\text { Substrate concentration } 10.0 \\
\mathrm{~g} / 100 \mathrm{~mL}\end{array}$ & $\begin{array}{c}\text { Agitation speed } 150 \mathrm{rpm} \\
50 \mathrm{gms}\end{array}$ \\
& & & $\begin{array}{c}\text { Sample load } \\
50 \mathrm{gms}\end{array}$ \\
\hline
\end{tabular}

The experiment of the optimized conditions obtained by the RSM based approach was investigated by performing an experiment in these optimized conditions. According to the experiments, the bacterial reduction efficacy and residual mass were found to be $15000 \mathrm{CFU} / \mathrm{mL}$ and $0.94 \mathrm{~g}$ at the end of the $4^{\text {th }}$ day, whereas the efficiencies optimized by RSM for bacterial count and residual mass were $16481.6 \mathrm{CFU} / \mathrm{mL}$ and $0.5426 \mathrm{~g}$ respectively. The

validation experiment and predicted values from fitted correlations were in close agreement with above $95 \%$ confidence interval. The result indicated that the predicted and actual values were in close agreement at a $95 \%$ confidence interval. Hence, the model was successful in predicting the effective treatment parameters. Figure 1. shows the beaker containing treatment samples initially and at the end of fourth day, where reduction in microbial population 
happened when some amount tissue was digested at the end of the fourth day, compared to the sample at $0^{\text {th }}$ day.

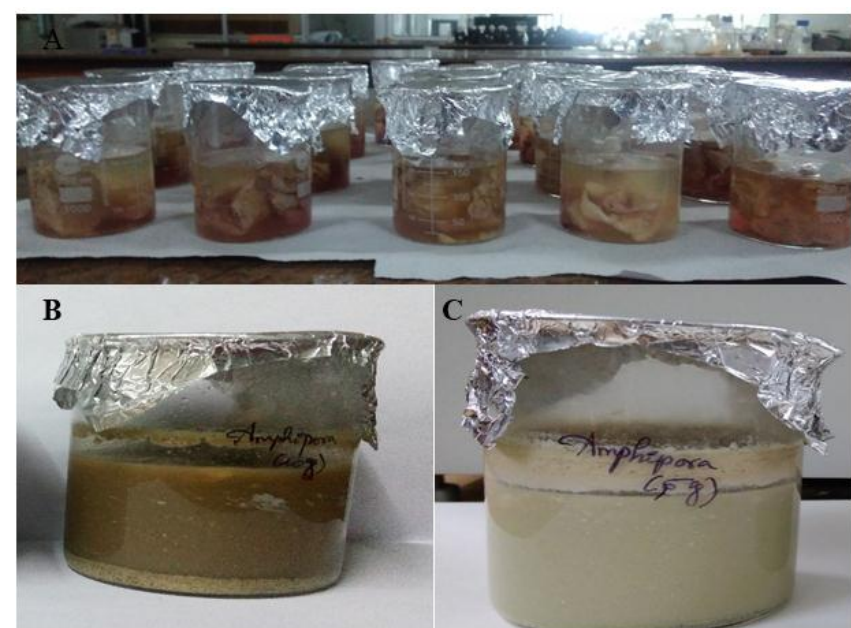

Figure 1: Samples at the end of primary treatment. A) $0^{\text {th }}$ day, B) $2^{\text {nd }}$ day and C) $4^{\text {th }}$ day

\begin{tabular}{|c|c|c|c|c|c|c|}
\hline \multirow[t]{2}{*}{$\mathrm{A}(\mathrm{g} / \mathbf{1 0 0 m L})$} & \multirow[t]{2}{*}{ B (rpm) } & \multirow[t]{2}{*}{$\begin{array}{l}\mathrm{C} \\
(\mathrm{hr})\end{array}$} & \multicolumn{2}{|c|}{$\begin{array}{l}\text { Bacterial count } \\
(\mathrm{CFU} / \mathrm{mL})\end{array}$} & \multicolumn{2}{|c|}{ Residual mass (g) } \\
\hline & & & Predicted & Experimental & Predicted & Experimental \\
\hline 10.2 & 150.41 & 91.13 & 16481.6 & 15000 & 0.5426 & 0.94 \\
\hline
\end{tabular}

At the end of the secondary treatment, where the tissue got completely digested, it was confirmed that the bacterial population got reduced at the end of the final treatment.

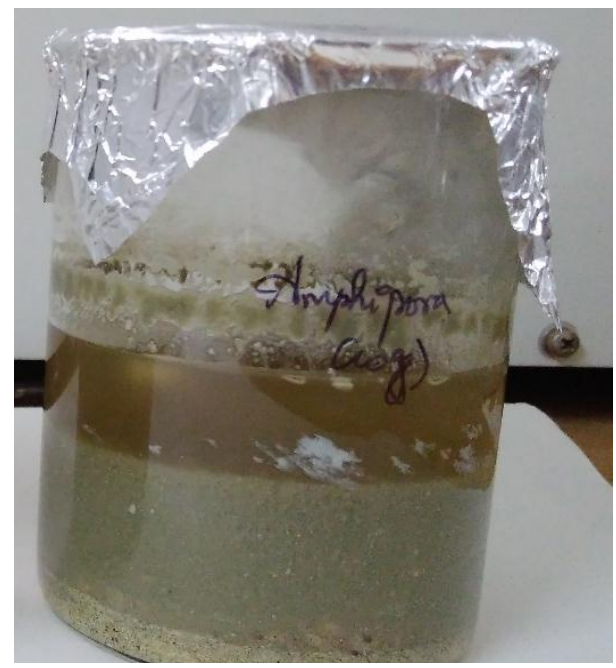

Figure 2: Sample at the end of secondary treatment

\section{Influence of Temperature on Treatment Process}

Alkaline hydrolysis method was done in order to inactivate the pathogens and it was carried out in the controlled environment where temperature was the major factor causing inactivation. To study the influence of temperature in the treatment procedure the experiment was done at different temperatures $\left(30^{\circ} \mathrm{C}, 35^{\circ} \mathrm{C}, 40^{\circ}\right.$ $\mathrm{C}, 45^{\circ} \mathrm{C}, 50^{\circ} \mathrm{C}, 55^{\circ} \mathrm{C}, 60^{\circ} \mathrm{C}, 65^{\circ} \mathrm{C}, 70^{\circ} \mathrm{C}$ and $\left.75^{\circ} \mathrm{C}\right)$. In this work, the influence of temperature was studied using $250 \mathrm{~mL}$ beaker which contained $100 \mathrm{~mL}$ of sterilized distilled water and $50 \mathrm{~g}$ of biomedical waste. The experiment was carried out with the optimized conditions of selected parameters $(5 \% \mathrm{NaOH}, 5 \%$ neem extract, and $150 \mathrm{rpm}$ ). After the treatment period of $1 \mathrm{hr}$., the sample was withdrawn and the bacterial population studied. It was observed that the bacterial count steadily decreased from 20000 to $5 \mathrm{CFU} / \mathrm{mL}$ of sample, when the temperature range varied from 30 to $75^{\circ} \mathrm{C}$.
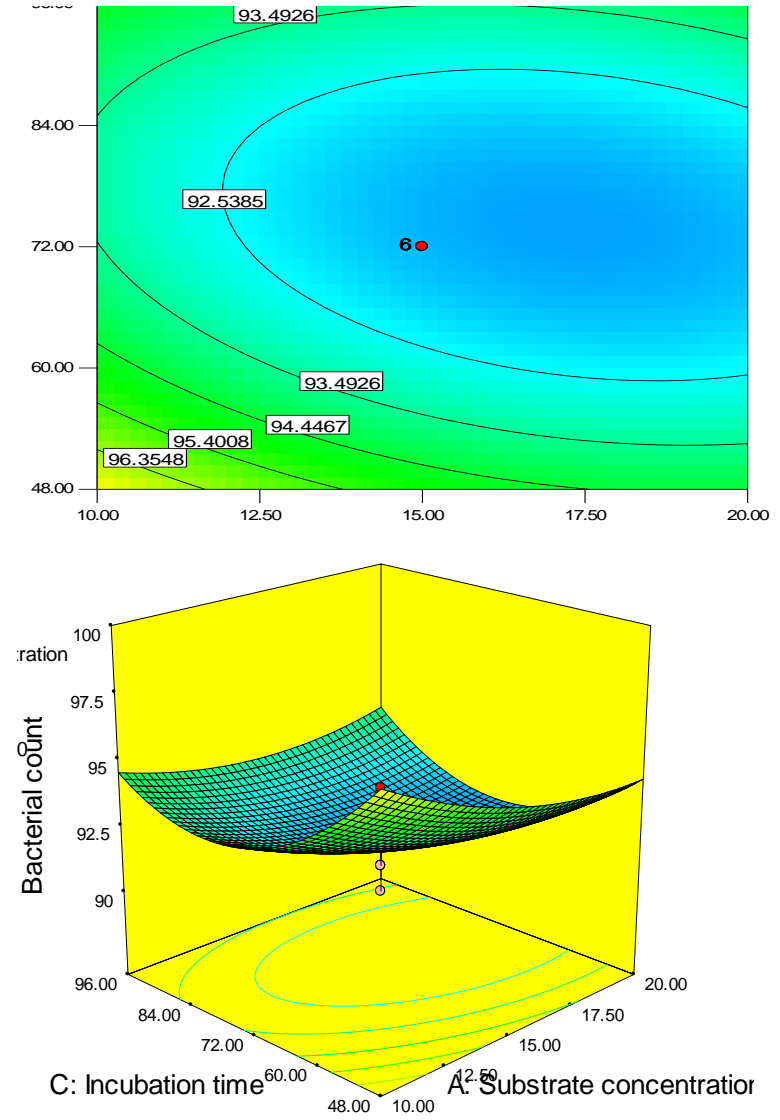

Figure 3: (a) contour and (b) surface plots for bacterial count with respect to Substrate concentration-Incubation time 


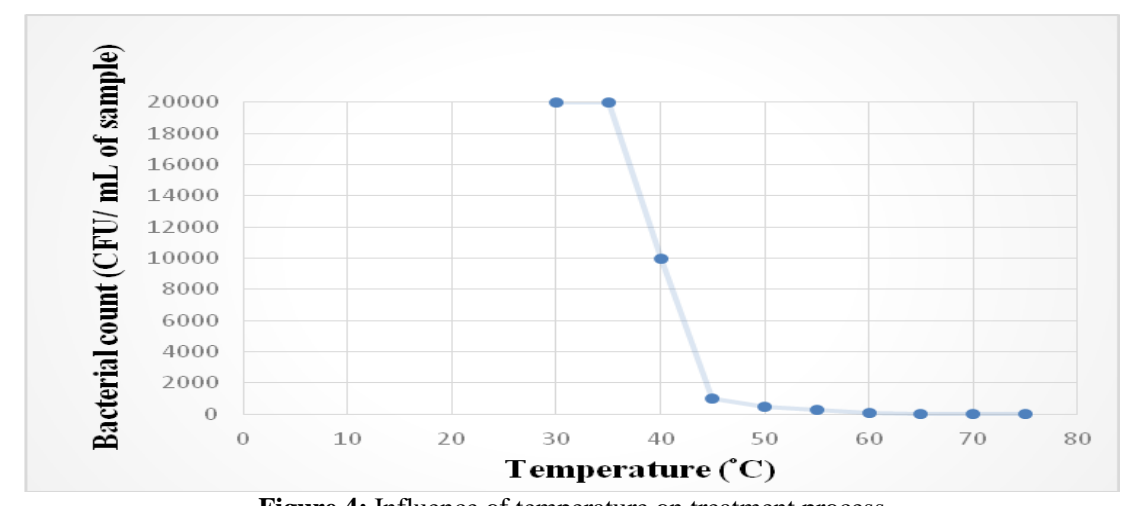

Figure 4: Influence of temperature on treatment process

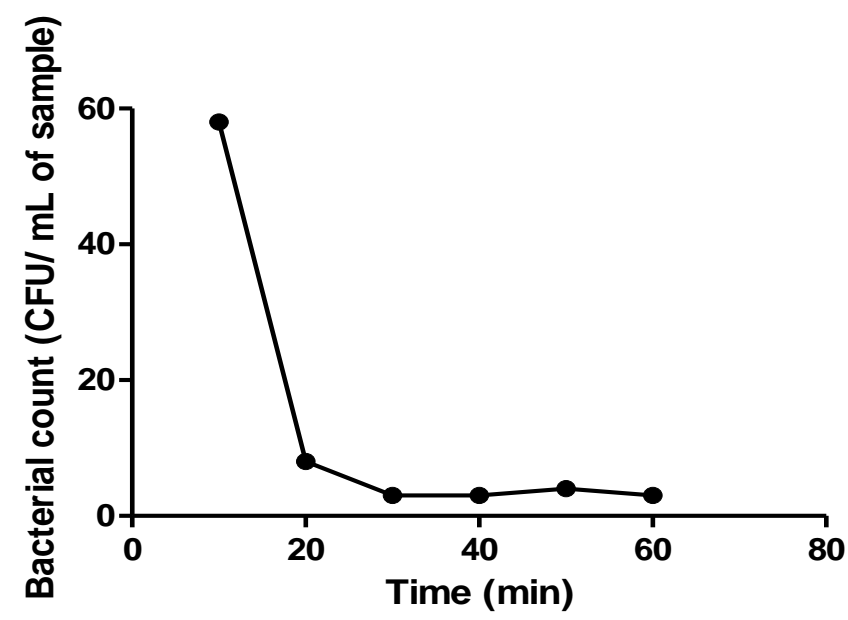

Figure 5: Effect of incubation time on treatment process

Table 3: Bacterial count at different concentrations of turmeric

\begin{tabular}{|l|c|c|c|c|c|c|}
\hline Substrate concentration $(\mathrm{g} / \mathrm{L})$ & $\mathbf{2 . 5}$ & $\mathbf{5 . 0}$ & $\mathbf{7 . 5}$ & $\mathbf{1 0 . 0}$ & $\mathbf{1 2 . 5}$ & $\mathbf{1 5 . 0}$ \\
\hline Bacterial Count $(\mathrm{CFU} / \mathrm{mL})$ & 100000 & 100000 & 98000 & 96500 & 96000 & 95000 \\
\hline
\end{tabular}

(At fixed values of Agitation speed, $150 \mathrm{rpm}$ and Incubation time, $48 \mathrm{hrs}$ )

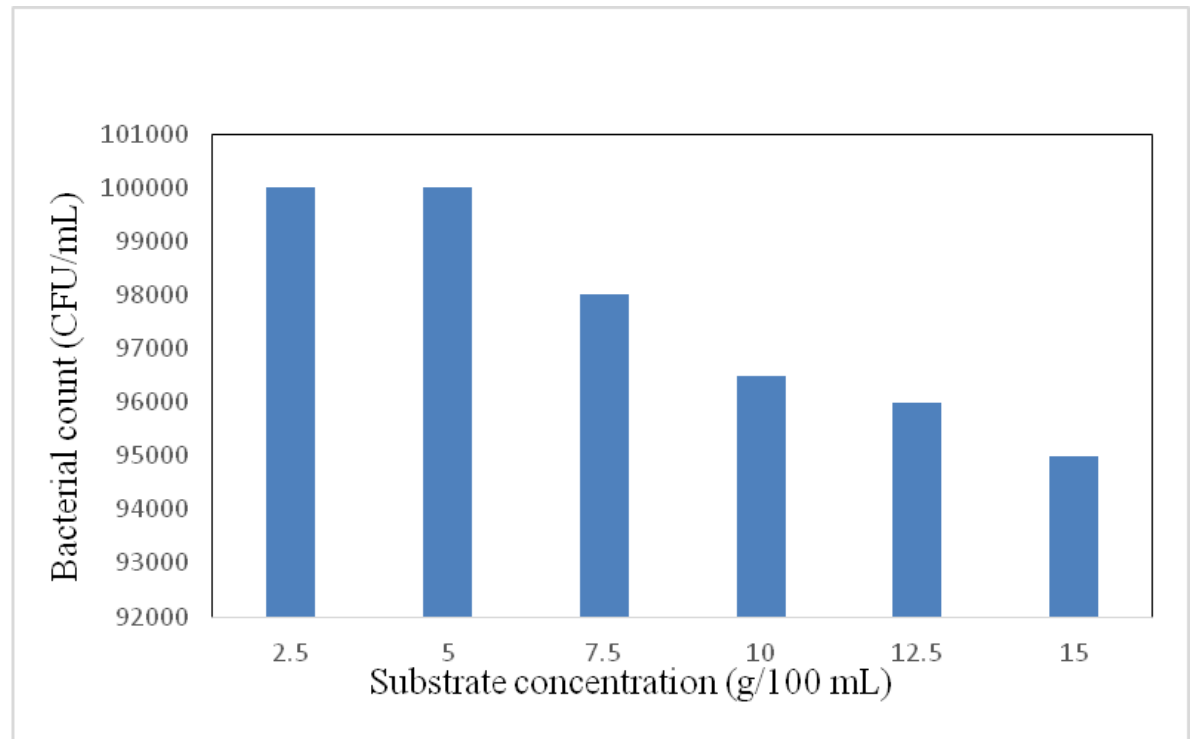

Figure 6: Bacterial population on different concentrations of turmeric PTS10 Variety

Table 4:Bacterial count at different agitation speed

\begin{tabular}{|l|c|c|c|c|c|}
\hline Agitation speed (rpm) & $\mathbf{5 0}$ & $\mathbf{1 0 0}$ & $\mathbf{1 5 0}$ & $\mathbf{2 0 0}$ & $\mathbf{2 5 0}$ \\
\hline Bacterial Count $(\mathrm{CFU} / \mathrm{mL})$ & & 98000 & 96000 & 95000 & 96000 \\
\hline
\end{tabular}




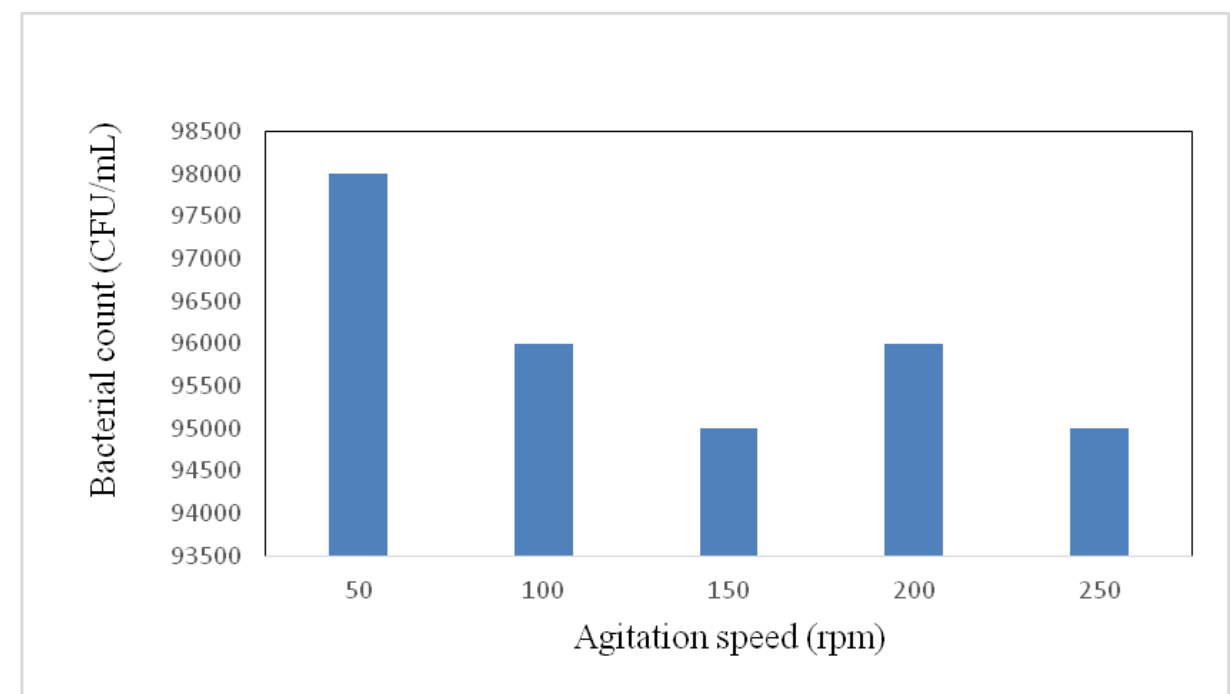

Figure 6: Bacterial populations on different agitation speed

Table 5: Bacterial count at different incubation period

\begin{tabular}{|l|c|c|c|c|c|}
\hline Incubation time (hrs) & $\mathbf{2 4}$ & $\mathbf{4 8}$ & $\mathbf{7 2}$ & $\mathbf{9 6}$ & $\mathbf{1 2 0}$ \\
\hline Bacterial Count $(\mathrm{CFU} / \mathrm{mL})$ & 98000 & 95000 & 92000 & 92000 & 91000 \\
\hline
\end{tabular}

(At fixed values of Substrate concentration, $10 \mathrm{~g} / 100 \mathrm{~mL}$ and agitation speed, $150 \mathrm{rpm}$ )

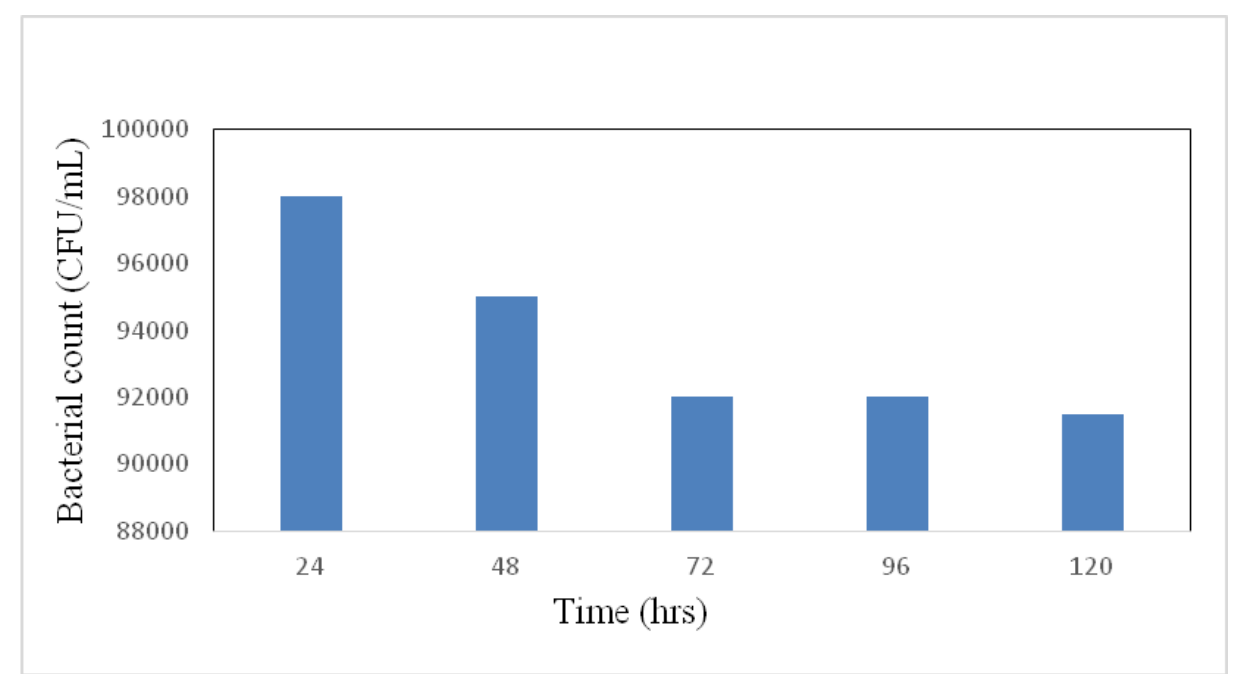

Figure 7:Bacterial population on different incubation period

\subsection{Effect of incubation time on treatment process (in presence of optimized temperature)}

Figure 5 shows the graphical representation of the bacterial count at different time intervals, which reveals that for an effective treatment of biomedical waste, after treatment using optimized conditions, it requires short period of incubation for the secondary treatment procedures. Efficiency of the bacterial reduction was obtained after the treatment of about 30 minutes. After that there was no change in the bacterial population which meant that the process had reached its saturation point.

\subsection{Parameter Optimization Using Response Surface Methodology}

In this study, three effective parameters (Substrate Concentration, Agitation Speed and Incubation Time) were selected as variables to be applied for the design of the experiment (DOE). Determining the central levels of the chosen parameters was important while implementing DOE. The central levels of the chosen parameters were determined from the results obtained by OVAT approaches. Since the optimization process was based on a 2-day period, the bacterial colony was determined at the end of the $2^{\text {nd }}$ day. The minimum bacterial population acquired after 2 days was taken as central levels.

While varying substrate concentration (Figure 6) from 2.5 to 15 $\mathrm{g} / 100 \mathrm{~mL}$ with constant agitation speed $(150 \mathrm{rpm})$, and Incubation Time (48 hrs), the minimum bacterial count of $95000 \mathrm{CFU} / \mathrm{mL}$ was obtained in the experiment conducted with the concentration of Substrate at $15 \mathrm{~g} / 100 \mathrm{~mL}$. It indicated that $15 \mathrm{~g} / 100 \mathrm{~mL}$ of substrate concentration was appropriate for bacterial reduction. In the experiments conducted at different agitation speed ranging from 50-250 rpm while keeping constant parameters such as Substrate Concentration $(15 \mathrm{~g} / 100 \mathrm{~mL})$, and Incubation Time (48 hrs) $95000 \mathrm{CFU} / \mathrm{mL}$ was obtained as minimum in the experiment operated with $150 \mathrm{rpm}$. The occurrence of reduced efficiency beyond $190 \mathrm{r} / \mathrm{min}$ might be due to a mechanical stress among pulp density, which created adverse conditions to attain sufficient oxygen requirement for microorganism growth. OVAT tests on Incubation time ranging 24-96 hrs indicated that the experiment at $72 \mathrm{hrs}$ showed an effective bacterial reduction to $92000 \mathrm{CFU} / \mathrm{L}$ by following constant parameters: substrate Concentration: 15 $\mathrm{g} / 100 \mathrm{~mL}$, Agitation speed: $150 \mathrm{rpm}$. It is apparent that $15 \mathrm{~g} / \mathrm{L}$ of substrate concentration, $150 \mathrm{rpm}$, and $72 \mathrm{hr}$ incubation period could be used as central level of variables for DOE studies. Using this central level of independent parameter variables, further studies for design-matrix interaction and optimization were carried 
out. The experimental response was done using central composite rotatable design (CCRD) for minimize bacterial count and residua mass and also the optimization of parameters (Chong et al., 2010).

\subsection{Preparation of Bio-manure}

Viability of the microorganisms was decreased. A complete destruction of the potentially infectious microbes took place after the primary and secondary treatments. As a result of the secondary treatment, digested sample contains the break down products of the tissues such as proteins, sugars, fats etc., The supernatant was removed and the residue kept under air to dry for $2 \mathrm{hrs}$. After that the produced bio-manure was characterized for use in the field.

\subsection{Characterization of Bio-manure}

The results are depicted in the Table 6. From the results it is understood that the nitrogen and phosphorous sources are enriched after the treatment procedures and the reduction in moisture content to $<2 \%$ helps to overcome the microbial degradation when applied in the field (Bernhart and Fasina, 2009).

Table 6: Nutritional composition of bio-manure

\begin{tabular}{|l|c|}
\hline Content & $\begin{array}{c}\text { Range } \\
(\mathbf{\%})\end{array}$ \\
\hline Total nitrogen & 4.5 \\
\hline Phosphorous & 1.8 \\
\hline Sodium & 0.9 \\
\hline Moisture content & 1.5 \\
\hline
\end{tabular}

\section{Conclusion}

Plant species mediated biomedical waste management system was considered as the key idea of this current research work with cost effective strategy, when compared to conventional method like rendering, composting, anaerobic degradation and incineration. The current disposal techniques adopted for the biomedical waste management are incineration and land fill. It provides uncontrollable process factors which may release toxic substances into the air. The treatment of biomedical waste with viable technology is an urgent need to eliminate all the risks to humans and the environment. The biomedical wastes (Category $3 \& 6$ ) were collected and segregated. In this study, effective parameters such as Substrate concentration, Agitation speed and Incubation time were optimized to enhance the reduction of bacterial population during preliminary treatment process. It was attempted to check the efficacy of different substrates including Amphiroa fragilissima, Padina tetrasomatica, turmeric PTS10 variety and turmeric BSR variety in the treatment process. Central composite rotatable design (CCRD) was employed for minimizing the bacterial count and residual mass and also its optimization. It is apparent that $15 \mathrm{~g} / \mathrm{L}$ of substrate concentration, $150 \mathrm{rpm}$ and $72 \mathrm{hr}$ incubation period could be used as central level of variables for DOE studies. The results showed that alkaline hydrolysis treatment carried out at a temperature range of $75^{\circ} \mathrm{C}$ for an incubation period of $30 \mathrm{~min}$ caused a tremendous decline in the bacterial count from 20000 to $5 \mathrm{CFU} / \mathrm{mL}$. Seaweed and turmeric had good antibacterial activity against pathogens associated with biomedical wastes and they also caused tissue degradation to some extent. Animal tissues were digested completely and converted into a noninfectious effluent as a bio-manure. As a result, bio manure could be produced at the end of the primary and secondary treatment processes and its characterization was studied too.

\section{References}

[1] Albert and Raleigh. (2011) "The Proper Care and Use of a Garbage Disposal", Disposal Magazine, Retrieved on 2017.
[2] Bernhart M. and Fasina O. O. (2009) "Moisture effect on the storage, handling and flow properties of biomedical litter", Waste Management, Vol. 29, No. 4, pp. 1392-8. doi: 10.1016/j.wasman.2008.09.005.

[3] Chong M. N., Zhu H. Y. and Jin B. (2010) "Response surface optimization of phytocatalytic process for degradation of congo red using H-titanate nanofiber catalyst", Chemical Engineering Journal, Vol. 156, No. 2, pp. 278 - 285.

[4] Cointreau-Levine S. (1997) "Occupational and Environmental Health Issues of Solid Waste Management", In Cointreau-Levine S. (ed), International Occupational and Environmental Medicine, Mes by, St. Louis (USA)

[5] Datta, P., Mohi, G.K. and Chander, J. 2018 "Biomedical waste management in India: Critical appraisal", J Lab Physicians. Vol.10, No.1, pp. 6-14.

[6] Gerayeli F., Ghojavand F., Mousavi S. M., Yaghmei S. and Amiri F. (2013) "Screening and optimization of effective parameters in biological extraction of heavy metals from refinery spent catalysts using a thermophilic bacterium", Separation and Purification Technology, Vol. 118, pp. 151.

[7] Gunnerson C. G. and Stuckey D. C. (1986) "Anaerobic digestion: principles and practice of biogas systems", World Bank Technical Paper No. 49, Washington, DC: World Bank.

[8] Gupta S. and Sadhana R. (2005) "A comparison of the antimicrobial activity of garlic, ginger, carrot, and turmeric pastes against Escherichia coli O157:H7 in laboratory buffer and ground beef', Foodborne Pathogenic Diseases, Vol. 2, pp. 330-340.

[9] Kumar G. S., Harish N., Shyaja M. D. and Salimath P. V. (2006) "Fress and bound phenolic anti-oxidant in amla (Emblicaofficinalis) and turmer (Curcuma longa)", Journal of Food Composition and Analysis, Vol. 19, pp. 446-452. doi: 10.1016/j.jfca.2005.12.015.

[10] Naz S., Safia J., Saiqa I., Farkhanda M., Farah A. and Aamer A. (2010) "Antibacterial activity of curcuma longa varieties against different strains of bacteria", Pakistan Journal of Botany, Vol. 42, pp. $455-462$.

[11] NRAES. (1999) "Biomedical Waste Management Handbook (NRAES-132)", Natural Resource, Agriculture, and Engineering Service, Cooperative Extension, 152 Riley-Robb Hall, Ithaca, NY 14853-5701.

[12] Rajan, R., Robin, D.T. and Vandanarani, M. (2018). "Biomedical waste management in Ayurveda hospitals - current practices \& future prospectives", Journal of Ayurveda and Integrative Medicine, https://doi.org/10.1016/j.jaim.2017.07.011

[13] Sakthieswari. and Srisudha. (2016) "Preliminary Study on Phytochemical Analysis, Mineral Composition and Antibacterial Properties of Amphiroa fragilissima (Linnaeus) Lamoroux and Ulva reticulata forsskal Collected from Mandapam Coast, Tamil Nadu", International Journal of Recent Scientific Research, Vol. 7, No. 6, PP. 12084-12089.

[14] Singh, A. and Kaur, S. (2012). Treatment and disposal. Biomedical waste disposal, (1st ed.), Jaypee Brothers Medical publishes, India, pp. 121-122.

[15] Tilak J. C., Meenal B., Hari M., Devasagayam T. P. A. "Antioxidant availability of turmeric in relation to its medicinal and culinary uses". Phytothermal Resources, 2004, Vol. 18, pp. 798 804.

[16] United Nations Statistics Division - Environment Statistics. Retrieved 3 March 2017. unstats.un.org.

[17] Zokaei K., Safdari J., Mousavian M. A. and Rashidi A. (2013) "Study of oxygen mass transfer coefficient and oxygen uptake rate in a stirred tank reactor for uranium ore bioleaching", Annals of Nuclear Energy, Vol. 53, pp. 280 